\title{
Considerations for physical employment standards in the aging workforce
}

\author{
David J.C. Flower*, Mike J. Tipton and Gemma S. Milligan \\ Extreme Environments Laboratory, Department of Sport and Exercise Science, \\ University of Portsmouth, Portsmouth, UK
}

\begin{abstract}
.
BACKGROUND: If current population and health trends continue, workplace demographics will look significantly different by the turn of the century. Organizations will no longer have a steady pipeline of younger workers and will likely need to rely on older workers to remain competitive in the global marketplace. The future multi-generational workforce will bring with it the challenge of maximizing contributions from each generation whilst at the same time addressing the health, safety and wellbeing needs of all workers.

OBJECTIVE: This review provides an insight into aging and older workers, and presents recommendations to promote worker longevity.

METHODS: This narrative review draws on evidence from 108 published sources.

RESULTS: The relationship between age and work is not simple; factors including the physical nature of the job and worker's health and fitness interact with age to either increase or decrease the potential effect of age. Evidence suggests that the issues arising from an aging workforce can be managed through polices that focus on active aging through: attitude management; flexible working and the provision of occupational health.

CONCLUSION: The integration of such interventions would require company and organizational commitment from the top down with educational programs at all levels to ensure understanding and participation.
\end{abstract}

Keywords: Aging worker, older worker, healthy worker effect

\section{Introduction}

The Executive Chair of the International Longevity Centre stated at the Global Summit on the Aging Workforce that, in her view, population aging is the greatest legacy of the 20th century and the greatest challenge of the 21st century [1]. Following the abolition in the UK of a legal retirement age (unless retirement age can be objectively justified), in October 2011, there is an increased need to pro-

\footnotetext{
*Address for correspondence: David J. C. Flower, Extreme Environments Laboratory, Department of Sport and Exercise Science, University of Portsmouth, Spinnaker Building, Cambridge Road, Portsmouth, Hants, PO1 2ER, UK. Tel.: +44 02392845358 ; Fax: +44 02392 843620; E-mail: david.flower@port.ac.uk.
}

vide opportunities for individuals to remain in post if they are able to meet the demands of the job. Thus, the use of Physical Employments Standards (PES) will play an important role in maintaining objectivity when managing the aging work force in jobs where there are high physical demands.

Over the next 30 years, in the European Union, the working-age population is expected to shrink at the rate of between 1 and 1.5 million people each year. In parallel, the number of people aged 60 years and over is expected to increase at the rate of about 2 million each year [2], thus it is likely state pension ages will continue to rise due financial reasons. The working-age population is already beginning to contract in several large developed countries, including 
Germany and Japan [3]. By 2030, it is predicted to be stagnant or contracting in nearly all developed countries, the only major exception being the US where couples are continuing to have more children than in Europe [3]. This is predicted to be the first time in human history where the oldest age groups are larger than the youngest [2].

According to a report by Age UK, there are nearly 900,000 people in the UK currently working past the age of 64, eight million aged 54 to 64 years, and a further 735,000 past the age of 50 years who want to be in the workforce [4]. This is partly driven by the abolition of the default retirement age, and the fact that state pension ages are set to rise to 66 by 2020 and 67 by 2026 for both men and women [4]. Similar employment trends are visible across Europe, Australia and Canada, where a U-shaped trend has been observed in which the number of men aged 60 to 64 years still in the labor force has occurred across the period from 1980 to 2016 [5]. In the US it is projected that by 2024, the labor force will grow to about 164 million people, of which approximately 41 million people will be aged 55 years and older, and approximately 13 million expected to be aged 65 years and older [6]. Despite similarities in trends, participation levels vary substantially across similar countries. For instance, only $30 \%$ of men aged 60 to 64 years in France were in the labor force in 2016, compared to $65 \%$ in Germany, $70 \%$ in the US and $75 \%$ in Sweden. Participation was highest in Japan, at 80\% [5]. For older women, there have been increases in participation in most countries with the biggest changes taking place where men's participation also rose substantially. For example, between 2000 and 2015, women's workforce participation increased approximately $20 \%$ in France, Austria, Italy and Australia, and $32 \%$ in Germany. Canada, the UK, Sweden and the US demonstrated smaller increases of: $17 \%, 14 \%$ $10 \%$ and $6 \%$ respectively [5]. Health, and in turn fitness for work, will become ever more important not just to secure pensions, but also to respond to both the changing age demographic and resultant labor shortages $[7,8]$. Thus, as the global population ages and working lives are extended there will be an increasing need to identify measurable and modifiable factors that influence the physical performance of the aging workforce and provide strategies to support the extension of working lives.

In addition, non-communicable disease and lifestyle-related health issues are rising and are responsible for over 35 million annual deaths globally, with a $60 \%$ increase anticipated by 2030 [9].
During the period 1980 to 2000, life expectancy for a 65 -year-old increased by 3 years for men, and 2.8 years for a woman, yet on average only 1 year was healthy, while the other 2 years are spent chronically ill [10].

Diseases that were more often seen in developed countries are now on the rise in emerging economies such as Mexico, India and China [11-13]. In Mexico, the major health concerns are related to cardiovascular disease and obesity, emerging trends show that Mexicans die younger than their counterparts in wealthier countries [11]. India is also experiencing health trends that have never previously been seen in their country. Although communicable diseases are still at the forefront of public health in India, cardiovascular disease and diabetes are rising [13]. It is predicted that in India 57.2 million people will have diabetes by 2025, many of whom will be of working age, and over the next 10 years chronic disease deaths will increase from $60 \%$ to as much as $77 \%$ [14]. Overall, non-communicable diseases and lifestyle-related health issues are rising with the UN anticipating a $60 \%$ increase by 2030 [9]. Thus, it is inevitable that the prevalence of chronic health conditions will impact into the workforce.

The likelihood of suffering from a long-standing condition and, at the same time, being able to continue working is, in some measure, dependent on the level of education of the worker [15]. Studies in Finland, France, the UK and US have highlighted that workers beyond the age of 50 years with low socio-economic position have an increased risk of health-related exit from employment [16]. Thus, the higher the level of education, the more likely the worker will be able to remain in work due, in part, to the nature and physical demands of their job i.e. those with higher levels of education tend to occupy less physically demanding roles [15].

It is clear that organizations will no longer have a steady pipeline of younger workers, and will need to rely on older workers to remain competitive in the global marketplace. In addition, with a shrinking workforce and a loss of older workers to retirement or 'bridging' jobs (e.g. jobs that have fewer hours, are less skilled and/or have lower physical demands) valuable knowledge, skills and experience will be lost, incurring significant replacement costs. Thus, the future multi-generational workforce will bring with it the challenge of maximizing the contributions of each generation whilst, at the same time, addressing the health, safety and wellbeing needs of all workers [17]. To accomplish this one of the first steps 
will be to predict where emerging health-based risks are likely to occur and better understand the health profiles of potential employees. These factors will be critical in helping to set health and business priorities in emerging markets and will place an emphasis on measuring and monitoring fitness for work. Secondly, appropriate assessment of both health (medical standards) and physical demands of the job (PES) will be required. The following sections will look to define the aging worker and investigate the impact age has on work, before reviewing existing policies and practices and highlighting future considerations.

\section{Definition of terms}

In dealing with an aging workforce, clarification as to what age best describes "an older worker" is required. The UK Health and Safety Executive (HSE) and scientific literature defines those over 50 years old to be "older workers" [18-24]. It is also pertinent to distinguish between an "older worker" and an "aging worker". Aging workers have been considered to be individuals 45 years and older [19]. But classifying someone as an older worker chronologically, does not mean people age at the same speed. Physically, age depends on genetics, health habits, illness, environment and occupation. Thus, it would be a mistake to think the relationship between age and an individual's capability to work is simple; there are many factors that can be classified as determinants of capability to work and age is only one of these.

\section{Aging and work}

There are a number of facts and misconceptions with respect to age, health status and employability for aging and older workers [22]. The following section examines the literature with regard to: physical work capacity and productivity; sensory abilities; cognitive function; fatigue and recovery; sick leave and accidents in the workplace.

\subsection{Physical work capacity and productivity}

Many occupations place a physical demand on their employees. In this context and in regard to an aging workforce, the preservation of the physical attributes to maintain the required outputs and promote the longevity of experienced workers is a key objective [25-27].
To understand the potential physical limitations associated with being able to meet the demands of a job and aging, it is important to look at the changes that occur in physical capacity with age. Three key factors affecting physical capacity are: cardiorespiratory function, muscular strength, and muscular endurance. A decline in any of these can limit an employee's ability to engage with occupational activities, especially if the physical demand is heavy [28]. For example, if a worker's physical work capabilities decline such that self-paced work becomes slower or set-paced work elicits more fatigue, work ability and productivity will be compromised [29].

Aging is associated with complex and diverse changes of cardiovascular structure and function (Table 1).

The decline in maximal aerobic capacity ( $\dot{V} \mathrm{O}_{2} \max$ ) can be as much as $50 \%$ from the age of 18 to 75 years old, with a steady decline across the age range reported in both males and females [33]. It has been suggested that peak aerobic performance can be maintained in elite performers until approximately 35 years of age, this is followed by modest decreases until 50 to 60 years, thereafter progressively steeper declines are observed [34-36]. Studies showed that aerobic training can lessen the impact of aging on $\dot{V} \mathrm{O}_{2}$ max, but it could not be maintained at the level of the younger athletes, which was attributed to a lower maximum heart rate in the older athletes [37]. Furthermore, it has been suggested that half of the age-related decreases in $\dot{V} O_{2}$ max could be attributed to an increase in body fat and a decrease in lean muscle mass resulting from a reduction in regular physical activity [38, 39]. Significant individual differences have been reported in aerobic and cardiovascular function due to lifestyle factors [37, 39-41]. Thus, maintaining a low body mass index (BMI), being physically active and not smoking are associated with higher cardiorespiratory fitness across the adult life span [36]. In the context of work, where tasks have a high aerobic demand, both maximal oxygen uptake $\left(\dot{V} O_{2} \max \right)$ and the ability to work at a sustained a percentage of $\dot{V} O_{2}$ max are important for completing work tasks [29, 42]. Thus, a decline in aerobic capability is linked to a reduction in work capacity.

Up to the age of 40 to 45 years, peak muscle force remains relatively constant. From 40 to 65 years there is a slight decline (e.g. approximately $5 \%$ per decade) which is accelerated thereafter. Reductions in peak muscle force mirror decreases in muscle fiber cross sectional area and selective atrophy of the fast twitch 
Table 1

Changes in aerobic/respiratory and cardiovascular function (adapted from [30-32])

\begin{tabular}{|c|c|}
\hline Aerobic/respiratory changes & Cardiovascular changes \\
\hline $\begin{array}{l}\text { Decreased lung function due to: } \\
\text { - Chest wall becomes more } \\
\text { ridged } \\
\text { - Total lung capacity stays the same } \\
\text { - Vital capacity decreases, } \\
\text { - Residual capacity increases } \\
\text { - Lungs become stiffer } \\
\text { - Muscle strength and endurance decreases }\end{array}$ & $\begin{array}{l}\text { Reduced cardiac output: } \\
\text { - Maximum heart rate } \\
\text { decreases } \\
\text { - Heart may increase in size offset by } \\
\text { thickening of the heart walls or } \\
\text { decreases with a heart size } \\
\text { decrease elasticity and increase } \\
\text { stiffness of the arterial system }\end{array}$ \\
\hline Decreased Alveolar surface area & $\begin{array}{l}\text { Heart rate and blood pressure take } \\
\text { longer to return to resting values }\end{array}$ \\
\hline $\begin{array}{l}\text { Decreased maximum breathing } \\
\text { capacity due to a decrease in lung } \\
\text { function }\end{array}$ & $\begin{array}{l}\text { Sensitivity of baroreceptors that } \\
\text { monitor blood pressure decreases }\end{array}$ \\
\hline Decreased tissue elasticity & Heart valves thicken \\
\hline
\end{tabular}

muscle fibers [32, 43-45]. Furthermore, elasticity, tensile strength and the capacity for the connective tissue to regenerate slows with age [32]. As with cardiorespiratory function, the magnitude of strength loss is controlled by levels of inactivity [29, 42]. Endurance training has been found to improve the aerobic capacity of muscle, and resistance training can improve central nervous system recruitment of muscle and increase muscle mass [44]. Physical activity throughout life is encouraged and perceived as optimal to prevent much of the age-related impact on skeletal muscle [44]. The American College of Sports Medicine (ACSM) has provided a position statement on resistance training in later life [24], which is a useful resource when considering training programs for the older worker.

Large individual variations exist for physical fitness, which is not only affected by age, but also by genetic factors, lifestyle factors, and the environment in which individuals live and work. This explains why highly trained older individuals are often able to outperform those who are younger, and remain in jobs with a high physical demand. The reason, perhaps, is because age has been reported to have lower correlations with performance outcomes than physical fitness [46] and experience when job tasks were reported as complex [47]. Furthermore, employees with the necessary capabilities may self-select to remain in an occupation with high physical demands, with their "experience" increasing their mechanical efficiency and therefore reducing the energy cost associated with a task [29, 48]. Age alone is not, therefore, a definitive predictor of the performance of individuals engaged in physically demanding occupations, and fitness appears to be a much stronger predictor of job performance. This effect shows that healthier workers in general, tend to work longer than those of poorer health and those who retire or transfer to jobs that are less physically demanding.

Self-selection may not be an option for some workers or employers, yet high physical workloads may not have the desired training effect on maintaining muscle strength in aging workers [49]. Thus, in order to ensure that workers who remain in post are motivated, healthier and maintain strength as they progress through their working life, it is recommended that, for physically demanding occupations, a physical fitness training program be integrated into the lifestyles of employees, aimed at maintaining cardio-respiratory and muscular fitness $[46,50]$.

\subsection{Sensory abilities}

As we age our vision naturally changes with decreases in visual acuity, particularly near-vision, light sensitivity, glare tolerance and color vision [50]. Worldwide $65 \%$ of visually impaired and $82 \%$ of all blind people are aged 50 years and over, with cataracts accounting for more than half of all blindness [51]. It has been shown that contrast sensitivity decreases with age [50] and that older truck drivers have difficulty with depth perception [52]. In addition, impaired vision may affect close, detailed work and display screen use, but need not affect job performance and in most cases deficiencies can be overcome by corrective eyewear or adaptive technology [53].

Structural and sensorineural degeneration occurs throughout the auditory system as we age causing hearing loss and balance problems [54]. The incidence of hearing loss in the US is $37 \%$ at 10 -year 
follow-up in adults aged 48-92 years [56]. Varying degrees of presbycusis are experienced by older adults, often with tinnitus, and the rate of progression of hearing loss is worsened by occupational exposure to noise [55]. Whilst hearing loss may not necessarily prevent an individual from remaining in work, working with hearing loss is tiring and makes maintaining optimal work performance more difficult [55].

Motor control and balance are important factors in preventing slips, trips and falls [57]. Both older male and female workers ( $\geq 45$ years) have been reported to have higher rates of these types of accidents [58]. This may be attributed to a change in motor control balance that arises from the specific impairment of neuromusculoskeletal factors [57], or the associated loss of vision with increasing age, which diminishes sensory input $[59,60]$.

Thus, consideration should be given to how these losses in sensory abilities directly impact on jobs where there is a high physical demand, and whether these attributes are adequately assessed within a PES.

\subsection{Cognitive function}

Cognitive function is considered to be critical in job performance as it is responsible for the processing of information. Cognition refers to attributes such as memory, ability to learn new information, speech and reading comprehension. Whilst some cognitive functions such as memory have been reported to deteriorate with age [41], some evidence would suggest that it is not a decrement in functioning but as the brain ages decreases in performance are compensated by activating other parts of the brain [61]. Some loss of cognitive function is inevitable with age and there is evidence to suggest older workers may be able to compensate for this loss, whilst demonstrating some more advanced cognitive skills [62]. Whilst this may be the case, differences between younger and older worker have nonetheless been highlighted [41, $61,63]$, for example, with regard to the slowing of reaction times and driving safety. It has been demonstrated that drivers under the age of 50 years have significantly faster response times across a variety of tasks compared to drivers aged 65 years and older, and that older drivers demonstrate significant deterioration in decision making skills compared to those under the age of 50 years [59].

It has been stated that there is limited literature specifically informing workplace and health policies about the needs and adaptations necessary for older workers who may be experiencing changes in cogni- tion [62]. The main problem with much of the work examining cognitive function and occupational capability is that it fails to replicate occupational demands, with volunteers performing cognitive skills above levels and intensities that might be required in an occupation. Those studies that have monitored workers over the course of their careers report far smaller declines in cognitive function than laboratory-based studies [64]. It has been suggested that institutional interventions should optimize learning environments by closely matching the information processing characteristics of the learner to the processing demands of the task $[65,66]$. To date the literature has not explored age and cognitive ability with respect to fatigue in occupational settings. Thus, critical task analyses, a key component of PES, are needed to allow future research to examine the difference in age with reference to cognitive capability during or following physically demanding tasks.

\subsection{Sick leave and accidents in the work place}

Despite the increase in the use of automated equipment and ergonomic assessments in many occupations to reduce the physical demand upon employees, a number of occupations still include physically demanding tasks, with musculoskeletal injury rates remaining high [67]. Approximately $28 \%$ of all injuries reported in the UK HSE statistics 2009/10, were as a result of manual materials handling. In the same period, injuries resulted in 5.1 million work days lost. Thus, the economic cost to organizations is great and accounts for $50 \%$ of all work-related absences [68]. These accident rates vary depending on the definition (e.g. injuries requiring three of more days from work), gender and occupation, although there is little evidence that conclusively suggests that older workers have more accidents than younger workers [69].

It has been reported that there is a relationship between age and heavy manual work leading to an increase in sciatic pain and the likelihood of back injuries [70], and an increased risk of musculoskeletal injury [71]. However, most of the literature has reported that accident rates decrease as age increases across a range of occupations, including the Fire and Rescue Service and construction industry [72-74] although some literature reports no difference across age $[59,75-77]$. The observed reduction in accident rate may be attributed to a lower exposure rate to certain high risk critical tasks, suggesting an informal redistribution of work tasks and differences in 
the types of jobs younger workers undertake and which play a critical role in their high-risk status [78]. Equally, this relationship may reflect the exclusion of older workers from work stresses they can no longer cope with. Alternative explanations are that the reduction in accidents could be due to increased perceptions of work safety [77], or that older workers with more experience (i.e. more years in the job) are associated with higher levels of efficiency and effectiveness.

Whilst accident rates are reported to be lower for older workers, accident severity and time to recover have been found to increase with age $[21,58,73,76$, $79,80]$, with those aged $\geq 45$ years being associated with a greater number of re-injuries [73]. In incidents of slips, trips and falls, older workers were more likely than younger workers to require hospitalization [75]. The increase in recovery time and re-injury rate may be attributed to muscle fiber atrophy, decreased muscle density, a reduction in balance and reaction times and increased intramuscular fat associated with aging [24, 57]. Musculoskeletal injuries associated with older workers may result from musculotendinous overload [60] which is further confounded by physical inactivity and deconditioning. In addition, the tensile strength of tendons has been reported to decrease with age. This culmination of effects results in decreased flexibility, which in turn increases the likelihood of tissue trauma, and further exasperates muscle imbalances leading to poor movement function and resulting in compensatory strategies, musculotendinous overload and ultimately injury [60].

The relationship between age, accident rates, injury and absence, is not simple. Whilst accident rates appear to drop as a result of age [72-74], the proportion and magnitude of injuries increases as a result of decline in functional capacity [60, 67]. The injuries of older workers appear to also be related to higher injury costs [80] which are due, in part, to the severity of the injuries sustained [80]. Furthermore, the nature of long term absences and duration of recovery appears to be positively related to age $[21,58,73,76,81]$. However, other factors such as the physical nature of the job and worker's health and fitness (the healthy worker effect) interact with age to either increase or decrease the potential impact of age [82]. The evidence would suggest that, the negative effect age may have on injury can be lessened if health and fitness is maintained. Thus, it is important that organizations promote and optimize worker's health and well-being in the work place.

\subsection{Fatigue and recovery}

With workers being expected to remain in employment longer, it has been suggested that an age-related imbalance may occur between workload and work capacity [83]. It has been suggested that this imbalance may occur from a decline in maximal physical work capacity of older workers that is not met with a corresponding reduction in physical work demands [84]. This imbalance can result in a decrease in physical reserves in relation to the daily demands of work, resulting in an overload that cannot be met in the time frame of recovery one day to the next [84]. This needs to be addressed in three ways; i) decrease the physical demand of the work where possible; ii) improve/maintain worker's physical capacity; iii) optimize recovery times.

Research has demonstrated that long-term health effects are preceded by short term effects [85]. These short-term effects are mostly experienced after the working day and signified by physical pain and signs of fatigue $[84,85]$. If the time to recover from work day fatigue is inadequate, cumulative effects will lead to long-term health problems, a decrease in work-ability (i.e. the physical capability required to perform work) and absences $[84,85]$. Thus, one of the concerns associated with older workers is the risk of overload from physical demanding occupations [86]. This raises an important question: "Do older workers with high work demands need more recovery from work?" There is limited occupational research related to recovery in older workers. However, the available studies have highlighted that older workers do indeed need more recovery than their younger counterparts $[86,87]$. This area of research (i.e. the need for recovery) clearly demonstrates the difference between younger and older workers; however, further work is required to determine how factors influence the magnitude of time needed to recovery from physical demanding work and whether this manifests over a working day or week. These implications could directly impact on those workers regularly required to perform work with high work demands. The ability to maintain performance over time should be assessed.

\subsection{Current practice and policies}

A multi-layered approach is required to manage older workers including the: monitoring of physical performance; analysis and understanding of organizations' current and projected workforce; 
implementation of polices to avoid age discrimination; accommodation of older workers and the facilitation of knowledge transfer between employees [88, 89].

In 1995 the first political declaration, "Resolution of Employment of Older Workers", targeted toward older workers was introduced in Europe and proposed that action should be taken to prevent the exclusion of older workers from the labor market by adapting working conditions and training programs to the needs of older workers. This has resulted in minimizing "early exit" strategies and promoting "healthy aging," In 2012 the European Union launched the "Year for Active Aging and Intergenerational Solidarity" as a means of disseminating good aging practices. The objectives of this directive were to achieve greater solidarity between generations through: i) active aging in employment; ii) encouraging active aging in the community; and iii) promoting independent living. This policy identifies the challenges facing the aging worker, employers and occupational services, and endorsed reforms for improving attitudes of management for age-related issues; better age-adjusted and flexible working parameters; and health services to better care for the aging worker [90]. These challenges have been translated into four policy dimensions (work environment, disease prevention and health promotion, flexible working, social context of work) which involve government, industry regulators, employers and individuals [90]. It has been suggested that workplace accommodations are vital in the management of the aging workforce. The UK Health and Safety Executive (HSE) recommendations from 2005 [22], 2010 [23] and 2012 [69] concluded that older workers do not need to be treated differently to younger workers, providing employers are aware that there may be a reduction in some physical and mental capabilities [22, 23]. In addition to lifestyle behaviors and personal interventions, the HSE recommend that there are a number of simple and effective workplace accommodations that employers can adopt as listed below $[22,23]$.

- Training provision for those over 50 years old should be improved [4, 18, 91-93].

- All jobs should be designed with flexibility in mind unless evidence shows there is a good reason for not doing so [4, 18, 91, 92, 94, 95].

- All employers should be willing to accept requests for flexible working $[4,18,96]$.
- Where appropriate, flexi-time and working from home should be considered [4, 18, 92, 94-96].

- Where appropriate, part time hours should be considered [93].

- All jobs should use phased retirement plans [91, 93].

- HR departments should be involved in order to drive change $[4,18]$.

- Selection should be based on objective measures, such as those used in the development and implementation of PES [95].

- Work place adjustments should be implemented e.g. moving to supervisory roles if the work is proving to physically demanding, moving to a "bridging" job prior to retirement [92].

- The health needs of older workers should be met, e.g. developing an occupational health service to: provide advice; make reasonable adjustments to their workplace $[4,92,94]$.

- Employers should implement work environment adjustments e.g. lighter equipment, providing power tools [92].

- Employers should work with employees to ensure that work performance can be properly measured regardless of working pattern [4, 95].

- Healthy lifestyles and physical activity should be promoted in an attempt to minimize the physiological decline of aging [24].

- Employers should consider the wider knowledge and awareness of working environments which can trigger ill health [either mental or physical) may lead to a wider adoption of preventative interventions in older workers [91].

Although there is considerable evidence that, with aging, working life can be managed through different polices, it remains unclear which are the most beneficial and/or cost effective to specific organizations [10].

\section{Discussion}

The importance of managing older workers, maintaining institutional skills, experience and knowledge is essential for productivity and profitability in all organizations, yet the relationship between age and work is not a simple one. Other factors such as the physical nature of the job, worker's health and lifestyle factors interact to alter work performance in relation to age $[82,97-101]$. It appears that age has a limited impact on work performance when older 
workers maintain the abilities required for satisfactory job performance and have the requisite level of expertise and fitness for the job [50, 82, 97]. Thus, it is important individuals have the physical capability to undertake the job, one way to ensure this is to implement a tasked-based PES, established independently of the consideration of subgroups, making the resulting standard age and gender "free" [102]. Alternatively, a PES could be used in occupations where public safety is not a factor, to inform job placement within an organization [103, 104]. This approach of using a PES to place workers into jobs which have been matched to their physical capabilities, may be more appealing to employers looking to retain aging employees.

Work alone does not appear to promote the health and fitness requirements necessary to maintain job performance [105-107]. Indeed, specific task-based training programs, nutritional education, occupational support, job adaptation, retirement plans and social interventions have the most significant effect on promoting working longevity [88, 105-108]. These interventions should not be focused on workers over a certain age but be an ongoing intervention through the working life (i.e. healthy older workers are healthy younger workers who age healthily). In order to optimize worker longevity, aging workers, employers and occupational services need to address: attitude, management (i.e. the knowledge of managers and supervisors in agerelated issues needs to be improved); work-life (i.e. better age-adjusted and flexible working); and the health services to better care for the aging worker [10].

Evidence has been presented that suggests that age-related factors in working life can be managed through a number of interventions, however, it remains unclear which are the most beneficial and/or cost effective [108]. This would suggest that each organization needs to develop individualized programs to manage older workers, specific to the job requirements. The integration of such interventions requires company and organizational commitment from the top down, with educational programs at all levels to ensure understanding and participation.

\section{Conflict of interest}

None to report.

\section{References}

[1] Greengross S, Editor The International Longevity Centre House of Lords The Pfizer Journal Global Summit on the Aging Workforce; 2005.

[2] Tucker C. European Commission. Demography, active aging and pensions. Social Europe Guide. In: Commision. E, editor. Luxembourg: Publications Office of the European Union, 2012, pp. 7-88. Available from: https://ec.europa.eu/eip/ageing/library/demographyactive-and-pensions-social-europe-guide-volume-31_enBrussels.

[3] Vaupel JW, Loichinger E. Redistributing work in aging Europe. Science. 2006;312(5782):1911-3.

[4] Brooks C, Iparraguirre J. A Means to Many Ends Age UK: Age UK; 2012 [cited 2017 June 2017]. Available from: https://www.ageuk.org.uk/globalassets/age-uk/documen ts/reports-and-publications/reports-and-briefings/activecommunities/rb_sept12_a_means_to_many_ends_older_wo rkers_experiences_of_flexible_working.pdf

[5] OECD. OECD Employment Outlook 2018. Available form: https://www.oecd-ilibrary.org/content/publication/ empl_outlook-2018-en

[6] Toossi M, Torpey E. Older workers: Labor force trends and career options United States Department of Labour: Bureau of Labour Statistics; 2017 [June 2018]. Available from: https://www.bls.gov/ careeroutlook/2017/article/older-workers.htm.

[7] Clancy G. Labour demand: The need for workers. Economic \& Labour Market Review. 2009;3(2):21-9. Available from: http://www.palgravejournals.com/ elmr/journal/v3/n2/pdf/elmr200924a.pdf?origin=publica tion_detail.

[8] Henkens K, Schippers J. Active ageing in Europe: The role of organisations. Int J Manpower. 2012;33(6):604-11.

[9] ICHLC. 2014 Trend Report. In: Council ICHL, editor. International Corporate Health Leadership Council International Corporate Health Leadership Council 2014. p. 2-56. Available from: https://www.ichlc.org/publications/2014-trend-report.

[10] Ilmarinen J. The ageing workforce-challenges for occupational health. Occ Med. 2006;56(6):362-4.

[11] Barquera S, Campos I, Rivera JA. Mexico attempts to tackle obesity: The process, results, push backs and future challenges. Obes Rev. 2013;14:69-78.

[12] French P, Crabbe M. Fat China: How expanding waistlines are changing a nation: Anthem Press; 2010.

[13] Yesudian CA, Grepstad M, Visintin E, Ferrario A. The economic burden of diabetes in India: A review of the literature. Globalization and Health. 2014;10(1):80.

[14] Pricewaterhousecoopers. Working Towards Wellness an Indian perspective. PRICEWATERHOUSECOOPERS: 2007. Available from: https://www.pwc.in/assets/ pdfs/india-publication-working-towards-wellness.pdf.

[15] Reinhardt JD, Wahrendorf M, Siegrist J. Socioeconomic position, psychosocial work environment and disability in an ageing workforce: A longitudinal analysis of SHARE data from 11 European countries. Occup Environ Med. 2013;70(3):156-63.

[16] Carr E, Fleischmann M, Goldberg M, Kuh D, Murray ET, Stafford M, et al. Occupational and educational inequalities in exit from employment at older ages: Evidence from seven prospective cohorts. Occup Environ Med. 2018;75(5):369-77. 
[17] Loeppke RR, Schill AL, Chosewood LC, Grosch JW, Allweiss $\mathrm{P}$, Burton WN, et al. Advancing workplace health protection and promotion for an aging workforce. J Occ Enviro Med. 2013;55(5):500-6.

[18] Chartered Management Institute \& MacLeod A. Managing an ageing workforce: How employers are adapting to an older labour market: Chartered Management Institute \& Chartered Institute of Personnel and Development; 2010. Available from: http://www.cipd.co.uk/ hrresources/survey-reports/managing-an-ageing-workfor ce-employers-are-adapting-to-an-older-labour-market. aspx.

[19] Taylor PE, Walker A. The ageing workforce: Employers' attitudes towards older people. Work, Employ Soc. 1994;8(4):569-91.

[20] Hotopp U. The employment rate of older workers. Labour Market Trends [Internet]. 2005 June 2017:[73-88 pp.]. Available from: http://citeseerx. ist.psu.edu/viewdoc/download;jsessionid=1D462463D90 F9E942625AA7A0FF59424?doi=10.1.1.457.4285\&rep= rep1\&type $=$ pdf.

[21] Pransky GS, Benjamin KL, Savageau JA, Currivan D, Fletcher K. Outcomes in work-related injuries: A comparison of older and younger workers. Am J Ind Med. 2005;47(2):104-12.

[22] Benjamin K, Wilson S. Facts and misconceptions about age, health status and employability. 2005. Available from: http://www.hse.gov.uk/research/hs1_pdf/2005/hs10520.pdf

[23] Yeomans L. An update of the literature on age and employment. Health and Safety Laboratory, Buxton, United-Kingdom. 2011. Available from: http://www.hse.gov.uk/research/rrpdf/rr832.pdf.

[24] Chodzko-Zajko WJ, Proctor DN, Singh MAF, Minson CT, Nigg CR, Salem GJ, et al. Exercise and physical activity for older adults. Med Sci. 2009;41(7):1510-30.

[25] de Zwart BC, Broersen JP, Frings-Dresen MH, van Dijk FJ. Musculoskeletal complaints in the Netherlands in relation to age, gender and physically demanding work. Int Arch Occ Env Hea. 1997;70(5):352-60.

[26] Johnson RW, Mermin GB, Resseger M. Job demands and work ability at older ages. Aging Soc Policy. 2011;23(2):101-18.

[27] McCarthy VJ, Perry IJ, Greiner BA. Has your work worked you too hard? Physically demanding work and disability in a sample of the older Irish population. Irish J Med Sci. 2013;182(1):47-55.

[28] Shephard R. Worksite health promotion and the older worker. Int J Ind Ergonom. 2000;25(5):465-75.

[29] Shephard R. Aging and productivity: Some physiological issues. Int J Ind Ergonom. 2000;25(5):535-45.

[30] Watkin D. The physiology of aging. Am J Clin Nutr. 1982;36(4):750-8.

[31] Ferrari AU, Radaelli A, Centola M. Invited review: Aging and the cardiovascular system. J Appl Physiol. 2003;95(6):2591-7.

[32] Harper S, Marcus S. Age-related capacity decline: A review of some workplace implications. Ageing Horizons. 2006;5:20-30.

[33] Shvartz E, Reibold R. Aerobic fitness norms for males and females aged 6 to 75 years: A review. Aviat Space Environ Med. 1990;61(1):3-11.

[34] Fleg JL, Morrell CH, Bos AG, Brant LJ, Talbot LA, Wright JG, et al. Accelerated longitudinal decline of aerobic capacity in healthy older adults. Circulation. 2005;112(5):674-82.
[35] Tanaka H, Seals DR. Endurance exercise performance in Masters athletes: Age-associated changes and underlying physiological mechanisms. J Physiol. 2008;586(1): 55-63.

[36] Jackson AS, Sui X, Hébert JR, Church TS, Blair $\mathrm{SN}$. Role of lifestyle and aging on the longitudinal change in cardiorespiratory fitness. Arch Intern Med. 2009;169(19):1781-7.

[37] Heath G, Hagberg J, Ehsani AA, Holloszy J. A physiological comparison of young and older endurance athletes. J Appl Physiol. 1981;51(3):634-40.

[38] Fleg JL, Lakatta EG. Role of muscle loss in the ageassociated reduction in VO2 max. J Appl Physiol. 1988;65(3):1147-51.

[39] Jackson AS, Beard EF, Wier LT, Ross RM, Stuteville JE, Blair SN. Changes in aerobic power of men, ages 25-70 yr. Med Sci Sports Exerc. 1995;27(1):113-20.

[40] Darr KC, Bassett DR, Morgan BJ, Thomas DP. Effects of age and training status on heart rate recovery after peak exercise. Am J of Physiol-Heart C. 1988;254(2 Pt 2):H340-3. PubMed PMID: 3344824. Epub 1988/02/01. eng.

[41] Ilmarinen JE. Aging workers. Occup Environ Med. 2001;58(8):546.

[42] Shephard R. Age and physical work capacity. Exp Aging Res. 1999;25(4):331-43.

[43] Aoyagi Y, Shephard RJ. Aging and muscle function. Sports Med. 1992;14(6):376-96.

[44] Kirkendall DT, Garrett WE. The effects of aging and training on skeletal muscle. Am J Sport Med. 1998;26(4):598-602.

[45] Frontera WR, Hughes VA, Fielding RA, Fiatarone MA, Evans WJ, Roubenoff R. Aging of skeletal muscle: A 12-yr longitudinal study. J Appl Physiol. 2000;88(4):1321-6.

[46] Davis PO, Dotson CO. Job performance testing: An alternative to age discrimination. Med Sci Sports Exerc. 1987;19(2):179-85.

[47] Avolio BJ, Waldman DA, McDaniel MA. Age and work performance in nonmanagerial jobs: The effects of experience and occupational type. Acad Manage J. 1990;33(2):407-22.

[48] Milligan GS, House JR, Tipton MJ. The physiological demand of pulling a rescue sled across the mud and the impact experience has on this task. Work. 2017;56(2):23945.

[49] Savinainen M, Nygård C-H, Korhonen O, Ilmarinen J. Changes in physical capacity among middle-aged municipal employees over 16 years. Exp Aging Res. 2004;30(1):1-22.

[50] Hitchcock L. Pilot performance. In: Garland DJ, Wise JA, Hopkin VD 1st ed: 1999, pp. 311-26.

[51] Zetterberg M. Age-related eye disease and gender. Maturitas. 2016;83:19-26.

[52] Llaneras RE, Swezey RW, Brock JF, Rogers WC, Van Cott HP. Enhancing the safe driving performance of older commercial vehicle drivers. Int $\mathrm{J}$ Ind Ergonom. 1998;22(3):217-45.

[53] Nicholson P, Mayho G, Robson S, Sharp C. Ageing and the workplace. A report from the BMA occupational medicine committee. London: British Medical Association. Retrieved from https://www.bma.org.uk//media/files/pdfs/practical-advice-at-work/occupational health/ageing-and-the-workplace.pdf; 2016.

[54] Howarth A, Shone G. Ageing and the auditory system. Postgrad Med J. 2006;82(965):166-71. 
[55] Fok D, Shaw L, Jennings MB, Cheesman M. Towards a comprehensive approach for managing transitions of older workers with hearing loss. Work. 2009;32(4):365-76.

[56] Cruickshanks KJ, Nondahl DM, Tweed TS, Wiley TL, Klein BE, Klein R, et al. Education, occupation, noise exposure history and the $10-\mathrm{yr}$ cumulative incidence of hearing impairment in older adults. Hear Res. 2010;264(12):3-9.

[57] Rogers MW, Mille ML. Lateral stability and falls in older people. Exerc Sport Sci Rev. 2003;31(4):182-7.

[58] Kemmlert K, Lundholm L. Slips, trips and falls in different work groups-with reference to age and from a preventive perspective. Appl Ergon. 2001;32(2):149-53. PubMed PMID: 11277507. Epub 2001/03/30. eng.

[59] Farrow A, Reynolds F. Health and safety of the older worker. Occ Med. 2012;62(1):4-11.

[60] Zuhosky JP, Irwin RW, Sable AW, Sullivan WJ, Panagos A, Foye PM. Industrial medicine and acute musculoskeletal rehabilitation. 7. Acute industrial musculoskeletal injuries in the aging workforce. Arch Phys Med Rehabil. 2007;88(3 Suppl 1):S34-9.

[61] Reuter-Lorenz PA. New visions of the aging mind and brain. Trends Cogn Sci. 2002;6(9):394-400.

[62] Melillo KD. Cognitive health and older workers: Policy implications. J Gerontol Nurs. 2013;39(6):13-8.

[63] Griffiths A. Ageing, health and productivity: A challenge for the new millennium. Work \& Stress. 1997;11(3):197214.

[64] Ardila A, Ostrosky-Solis F, Rosselli M, Gomez C. Age-related cognitive decline during normal aging: The complex effect of education. Arch Clin Neuropsychol. 2000;15(6):495-513.

[65] Tomporowski PD. Performance and perceptions of workload among young and older adults: Effects of practice during cognitively demanding tasks. Educ Gerontol. 2003;29(5):447-66.

[66] Charness N. Aging and human performance. Human Factors. 2008;50(3):548-55.

[67] Okunribido OOW, T. Ageing and work-related musculoskeletal disorders. Health and Safety Executive report RR799. Health and Safety Executive: Health and Safety Executive, 2010 Contract No.: RR799. Available from: http://www.hse.gov.uk/research/rrpdf/rr799.pdf.

[68] Hussey L, Turner S, Thorley K, McNamee R, Agius R. Work-related sickness absence as reported by UK general practitioners. Occ Med. 2012;62(2):105-11.

[69] Beers HB, Butler C. Age related changes and safety critical work: Identification of tools and a review of the literature. Health and Safety Executive. Health and Safety Executive: Health and Safety Executive, 2012. Anvaliable from: http://www.hse.gov.uk/research/rrhtm/rr946.htm.

[70] Nurminen M. Reanalysis of the occurrence of back pain among construction workers: Modelling for the interdependent effects of heavy physical work, earlier back accidents, and aging. Occup Environ Med. 1997;54(11):807-11.

[71] Virokannas H, Rahkonen M, Luoma I, Rajala U, Uusimaki A. Long-term musculoskeletal disorders and work career in 55-year-old workers. Exp Aging Res. 1999;25(4):301-6.

[72] Harry S, Mayr J, Haines T. Overview of the relationship between organizational and workplace factors and injury rates. Safety Sci. 1997;26(3):201-17.

[73] Cloutier E, Champoux D. Injury risk profile and aging among Québec firefighters. Int $\mathrm{J}$ Ind Ergonom. 2000;25(5):513-23.
[74] Gyekye SA, Salminen S. Age and workers' perceptions of workplace safety: A comparative study. Int J Aging Hum Dev. 2009;68(2):171-84.

[75] Layne LA, Pollack KM. Nonfatal occupational injuries from slips, trips, and falls among older workers treated in hospital emergency departments, United States 1998. Am J Ind Med. 2004;46(1):32-41.

[76] Peek-Asa C, McArthur DL, Kraus JF. Incidence of acute low-back injury among older workers in a cohort of material handlers. J Occup Environ Hyg. 2004;1(8): 551-7.

[77] Crawford JO, Graveling RA, Cowie HA, Dixon K. The health safety and health promotion needs of older workers. Occ Med. 2010;60(3):184-92.

[78] Breslin FC, Smith P. Age-related differences in work injuries: A multivariate, population-based study. Am J Ind Med. 2005;48(1):50-6.

[79] Salminen S. Have young workers more injuries than older ones? An international literature review. J Safety Res. 2004;35(5):513-21.

[80] Schwatka NV, Butler LM, Rosecrance JR. An aging workforce and injury in the construction industry. Epidemiol Rev. 2012;34:156-67.

[81] Thomson L, Griffiths A, Davison S. Employee absence, age and tenure: A study of nonlinear effects and trivariate models. Work \& Stress. 2000;14(1):16-34.

[82] van Emmerik H, Peeters MCW. An introduction to the work and well-being of older workers: From managing threats to creating opportunities. J Manage Psychol. 2008;23(4):353-63.

[83] de Zwart BC, Frings-Dresen MH, van Dijk FJ. Physical workload and the aging worker: A review of the literature. Int Arch Occup Environ Health. 1995;68(1):1-12.

[84] Ilmarinen J. Physical requirements associated with the work of aging workers in the European Union. Exp Aging Res. 2002;28(1):7-23.

[85] Sluiter JK, van der Beek AJ, Frings-Dresen MH. The influence of work characteristics on the need for recovery and experienced health: A study on coach drivers. Ergonomics. 1999;42(4):573-83.

[86] Devereux J, Rydstedt L. Does the older workforce with high work demands need more recovery from work. P Bust Taylor and Francis, London, UK, 2009, pp. 189-96.

[87] Kiss P, De Meester M, Braeckman L. Differences between younger and older workers in the need for recovery after work. Int Arch Occup Environ Health. 2008;81(3):311-20.

[88] Boudiny K. 'Active ageing': From empty rhetoric to effective policy tool. Ageing Soc. 2013;33(6):1077-98.

[89] Ollier-Malaterre A, McNamara T, Matz-Costa C, PittCatsouphes M, Valcour M. Looking up to regulations, out at peers or down at the bottom line: How institutional logics affect the prevalence of age-related HR practices. Hum Relat. 2013;66(10):1373-95.

[90] Kirkland KD, Dobbin D. Editor Public policy options for an ageing workforce. Healthy Aging for a Sustainable Workforce; 2009; National Labor College in Silver Spring, Maryland: The Centre for Construction Research and Training; 2009. Avaliable from: https://www.cpwr.com/sites/default/files/publications/Agi ng\%20Workers\%20Workshop\%20Report_11\%2009_Fin al.pdf.

[91] Barnes H, Smeaton D, Taylor RF. An ageing workforce: The employer's perspective. Institute for Employment Studies; 2009. Avaliable from: http://www.employmentstudies.co.uk/pdflibrary/468.pdf. 
[92] Houses of Parliament POoSaTAAW. Houses of Parliament, Parliamentary Office of Science and Technology. (2011). An Ageing Workforce. POSTNOTE [Internet]. 2011 June 2018; (391):[1-4pp.]. Available from: https://www.parliament.uk/pagefiles/504/postpn391_Agei ng-Workforce.pdf.

[93] Department of Workplace Pensions (DWP). Employing older workers: An employer's guide to today's multi-generational workforce. DWP London; 2013.Avaliable from: https://www.gov.uk/go vernment/uploads/system/uploads/attachment_data/file/14 2751/employing-older-workers.pdf.

[94] McNair SF, Flynn M, Worman D, Willmott B. Managing a healthy ageing workforce: A national business imperative. Chartered Institute of Personnel Development (CIPD), 2012. Avaliable from: http://www.cipd.co.uk/binaries/5754Managingageingwor kforceWEB.pdf.

[95] CIPD; Age Posi+ive; DWP. Performance and retirement practices - get it right. Chartered Institute of Personnel Development and, Age Posi+ive, Department of Work Place Pensions. 2012. Avaliable from: http://hospeem.org/wp-content/uploads/2014/02/GuideEmployers-Performance_Retirement-Practices.pdf.

[96] BIS. Phasing out the Default Retirement Age: Government Response to Consultation. Department for Business Innovation and Skills London; 2011.Avaliable from: http://www.bis.gov.uk/assets/biscore/employmentmatte $\mathrm{rs} / \mathrm{docs} / \mathrm{p} / 10-1047$-default-retirement-age-consulta tion.pdf.

[97] Jones MK, Latreille PL, Sloane PJ, Staneva AV. Workrelated health risks in Europe: Are older workers more vulnerable? Soc Sci Med (1982). 2013;88:18-29.

[98] Au DW, Crossley TF, Schellhorn M. The effect of health changes and long-term health on the work activity of older Canadians. Health Econ. 2005;14(10):999-1018.

[99] Alavinia SM, Burdorf A. Unemployment and retirement and ill-health: A cross-sectional analysis across European countries. Int Arch Occup Environ Health. 2008;82(1): $39-45$.
[100] Robroek SJ, Schuring M, Croezen S, Stattin M, Burdorf A. Poor health, unhealthy behaviors, and unfavorable work characteristics influence pathways of exit from paid employment among older workers in Europe: A four year follow-up study. Scand J Work Environ Health. 2013;39(2):125-33.

[101] van den Berg T, Schuring M, Avendano M, Mackenbach J, Burdorf A. The impact of ill health on exit from paid employment in Europe among older workers. Occup Environ Med. 2010;67(12):845-52.

[102] Tipton M, Milligan G, Reilly T. Physiological employment standards I. Occupational fitness standards: Objectively subjective? European J Appl Physiol. 2013;113(10):243546.

[103] Armstrong TJ, Franzblau A, Haig A, Keyserling WM, Levine S, Streilein K, et al. Developing ergonomic solutions for prevention of musculoskeletal disorder disability. Assist Technol. 2001;13(2):78-87.

[104] Pransky GS, Dempsey PG. Practical aspects of functional capacity evaluations. J Occup Rehabil. 2004;14(3):21729.

[105] Karazman R, Kloimuller I, Geissler H, KarazmanMorawetz I. "Effect typology" and work ability index: Evaluating the success of health promotion in elder workforce. Exp Aging Res. 1999;25(4):313-21.

[106] Holtermann A, Jorgensen MB, Gram B, Christensen JR, Faber A, Overgaard K, et al. Worksite interventions for preventing physical deterioration among employees in job-groups with high physical work demands: Background, design and conceptual model of FINALE. BMC Public Health. 2010;10:120.

[107] Strijk JE, Proper KI, van der Beek AJ, van Mechelen W. A worksite vitality intervention to improve older workers' lifestyle and vitality-related outcomes: Results of a randomised controlled trial. J Epidemiol Commun $\mathrm{H}$. 2012;66(11):1071-8.

[108] Oxley H. Policies for healthy ageing. 2009. Available from: http://www.nusentrepreneurshipcentre.sg/ userfiles/files/OECD\%20healthy\%20ageing.pdf. 